American J. of Engineering and Applied Sciences 2 (2): 360-364, 2009

ISSN 1941-7020

(C) 2009 Science Publications

\title{
Determination of Kinetic Correction Coefficient of Fluid Flow Using a Generic Multiple Orifice Physical Scale Model Structure
}

\author{
Emmanuel M. Adigio \\ Department of Mechanical Engineering, Niger Delta University, \\ Wilberforce Island Bayelsa State, Nigeria
}

\begin{abstract}
Problem statement: Diesel particulate filters are fast becoming integral parts of diesel engines, light and heavy duty, due to their potential in the reduction of particulate matter from exhaust gases and their noise muffling property. Consequently, several researchers are developing mathematical models for the study of fluid flow through the filter substrate and in the aiding of filter systems design. Recently, some researchers developed a mathematical model known as the Multiple Orifice Mathematical (MOM) model for determining pressure gradients of gelcast ceramic foams. The MOM model was calibrated using fluid flow data from cellular foam filter structure similar to ceramic foams. However, there was need to improve on the method of calibrating the model. Approach: Following the conceptual model employed in the development of the MOM model, a physical scale model was designed using a $\mathrm{CAD}$ package and manufactured for the purpose of measuring pressure drops across the connecting windows of the cells. A new fluid flow rig was also designed from a CAD package and fabricated to adapt to the physical scale model. Applying the conservation theory, the flow rates across the windows were calculated and equated to the flow rate determined from an orifice meter, where the correction coefficients for the calibration of the MOM model were calculated. Results: A number of correction coefficients were calculated from the data collected from the experimental rig. The average correction coefficient which was used for the calibration of the MOM model was found to be 2.24. Conclusion/Recommendations: The result obtained from the new method of model calibration corroborated the value determined by earlier researchers. This new method reduced the computational time of calibrating the MOM model and eliminates the use of graphs and graph fitting. The new fluid flow rig and the physical scale model can be used in the study of fluid flow in other types of filter substrates.
\end{abstract}

Key words: Diesel particulate trap, gelcast ceramic foam, kinetic correction coefficient, generic foams, foam filters, pressure gradients

\section{INTRODUCTION}

While diesel engines have many advantages including low emission of carbon dioxide, fuel tolerance, robustness, low cost and high low-speed torque, they have the disadvantage of emitting significant amounts of Particulate Matter (PM) and oxides of nitrogen $\mathrm{NOx}^{[1]}$. Diesel exhaust emissions are reported to affect human health, contribute to acid rain and reduced visibility ${ }^{[2-10]}$. Consequently, governments of the United States, Japan and many European countries are enforcing stringent diesel emissions standards.

Although engine manufacturers have made a substantial reduction in emissions through improved engine design ${ }^{[11,12]}$, studies show that Diesel Particulate Filters (DPFs) are a potential exhaust after treatment technology for the reduction of PM emissions. DPFs consist of a filter designed to collect the PM in the exhaust stream of the diesel engine, while allowing the exhaust gases to pass through the system. In practical application, most DPFs can reduce the amount of particulates from diesel engine exhaust gas by at least $90 \%$ by mass across the whole range of particulates sizes $^{[12-14]}$.

The choice of a filter material depends on many factors including filtration efficiency, pressure drop, durability and cost effectiveness and mathematical modeling is increasingly becoming an engineering tool to understand, predict and control these parameters in DPF systems. Consequently, several researchers ${ }^{[15]}$ have proposed some models for predicting pressure drop across wall flow filters and filtration efficiency.

Considering the many advantages of Ceramic Foam (CF) filters, including their use as substrate in diesel particulate trap systems and Gelcast Ceramic 
Foam (GCF) in particular, some researchers ${ }^{[16]}$ reported the development of a mathematical model referred to as "Multiple Orifice Mathematical (MOM) model" for understanding fluid flow through the filters and an aid for filter design. This mathematical model was developed by applying the fluid flow theory on a simplified conceptual model, where the ceramic foam is represented with rows of cells across the filter, connected by openings called the windows. The resultant mathematical model was calibrated by fixing the viscous correction coefficient to determine the kinetic correction coefficient $\beta$, by "graph fitting" the mathematical model on a graph developed from experimental data of fluid flow on a physical scale foam model filter.

This report presents the calibration of the MOM model applying a direct experimental method of determining $\beta$ by using data of fluid flow experiment on a new physical scale model similar to the conceptual model used in developing the MOM model.

\section{MATERIALS AND METHODS}

Physical scale model: A physical scale model was designed using a Computer Aided Design (CAD) package and manufactured by using stereolithography rapid manufacturing techniques. In order to produce significant number of experimental data, two generic multiple orifice structures of diameter $60 \mathrm{~mm}$ and length $100 \mathrm{~mm}$ were produced with four rows of cells each. The rows of cells were of various cell/window ratios, providing enough variation for comparison. Figure 1 is a CAD drawing of the generic multiple orifice structure showing the rows of cells. Several sets of tapings were made along the length of the foam model as shown on the CAD drawing for the purpose of reading the pressure drop across the windows. The study of each row of cells and windows is a direct application of the conceptual model used for the development of the MOM model ${ }^{[16]}$.

Experimental set up: Two options for the measurement of the pressure difference across the windows were considered. The first option was to mount the generic structure directly in a filter holder of $60 \mathrm{~mm}$, where air flow is directed through a single row of cells by blocking the other three rows. However, it can be recalled that the change of the fluid flow diameter from 60-8-10 mm would be significant and the fluid flow through a row will not be fully developed when taking the readings across the windows. Hence, the second option was employed, which involved the reduction of the fluid flow diameter away from the entry to the row of cells to allow the fluid to be fully developed before the measurement of the pressure drops.

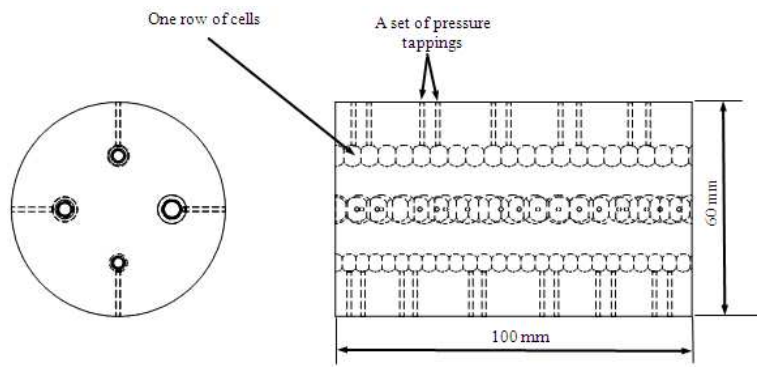

Fig. 1: Drawing of generic multiple orifice physical scale model designed using a computer assisted design package, where each row of cells corresponds to a given ratio of window to cell diameter

Consequently, a sample holder was designed and produced such that the air flow could be directed to a given row of cells and it (i.e., the holder) could be fitted to a flange on the pipe after an orifice flow meter. The length of the pipe that leads to the row of cells was $>50$ times the diameters of the cells to allow the fluid to be fully developed before the rows of cells. Figure 2 is a schematic of the multiple orifice physical scale model flow rig. The reducer pipe or connecting pipe of internal diameter $4.2 \mathrm{~mm}$ and length $450 \mathrm{~mm}$ is mounted after the orifice plate, then the sample was mounted on the other end such that reading can be taken from each given row of cells.

Steel tubes of external diameter $5 \mathrm{~mm}$ were inserted into the pressure tapping holes in the row of cells from which they were connected to flexible hose from the digital pressure gauges (Fig. 3). Soap solution was used to check for air leakage after using sealants.

The pressure drops across the windows were read from digital pressure gauges with ranges from 0$700 \mathrm{~Pa}$. The readings were taken simultaneously with that of the flow meter mounted before the physical model. The temperatures of the air were also read simultaneously to calculate the air densities.

The air flow through the rig was generated by a "Leister Robust" blower. The air flow rate was measured with an orifice plate meter. Specifications for the production of the orifice plate flow meter used in this research study are reported in the British StandardsISO $5167^{[17]}$. Between the blower and the flow meter was installed a flow conditioner, to straighten the swirling air flow and reduce the pulsation of the pressure across the orifice plate. The distance from the conditioner to the orifice plate was more than ten times the pipe diameter to allow the full development of the fluid flow before the orifice plate. 


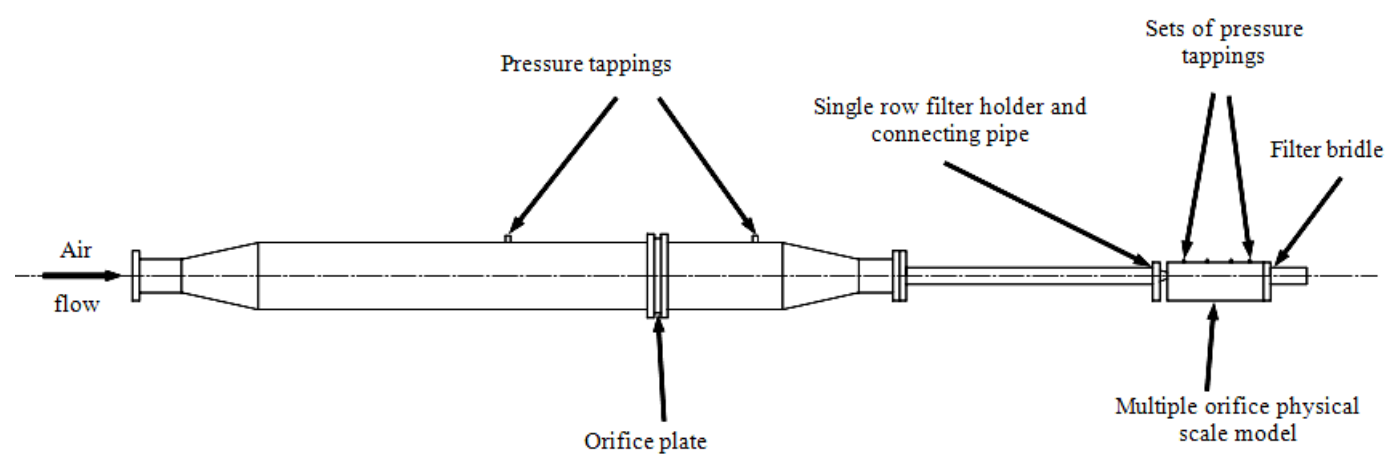

Fig. 2: Schematic of multiple orifice physical scale model flow rig

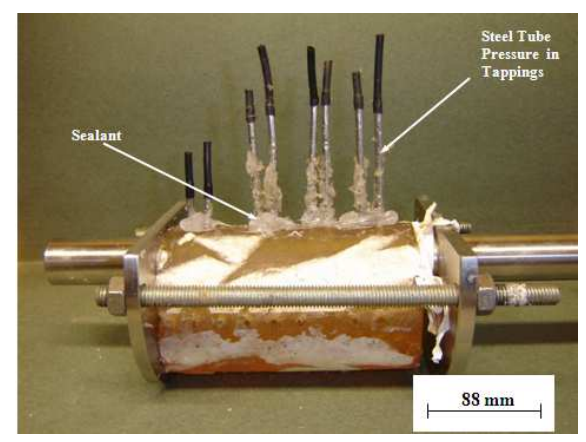

Fig. 3: Picture of the mounted sample of the multiple orifice scale model with the inserted steel tubes, sealed with sealant

Air with a known flow rate was directed through each of the rows of cells at a time and the pressure difference across the windows was measured from the pressure tapings.

Modeling of fluid flow rate across the windows: The objective of the experimentation is to measure the pressure drop across the windows of a given row of cells for a known fluid flow rate. Hence, each row of cells consists of 4 sets of pressure tapings to enable the measurement of the pressure drop across four windows at a time. Using the same principle for the development of the MOM model, a relationship was made between the pressure drop across the windows and the flow rates. From the conservation theory, the flow rate across the windows was equated to the flow rate calculated from the orifice meter.

The flow rate from the orifice plate was calculated from using the equation below derived from the Bernoulli equation:

$$
\rho \mathrm{Q}=\mathrm{C}_{\mathrm{D}} \frac{\pi}{4} \mathrm{D}_{\mathrm{O}}^{2} \sqrt{\frac{2 \rho \Delta \mathrm{P}}{1-\left(\frac{\mathrm{D}_{\mathrm{O}}}{\mathrm{D}_{1}}\right)^{4}}}
$$

Where:

$\mathrm{Q}=$ The flow rate $\left(\mathrm{m}^{3} \mathrm{sec}^{-1}\right)$

$\mathrm{C}_{\mathrm{D}}=$ The orifice plate discharge coefficient

$\mathrm{D}_{\mathrm{O}}=$ The orifice diameter $(\mathrm{m})$

$\mathrm{P}=$ The fluid density $\left(\mathrm{kg} \mathrm{m}^{-3}\right)$

$\mathrm{D}_{1}=$ The pipe diameter

$\Delta \mathrm{P}=$ The pressure drop across the orifice plate

A number of discharge coefficient equations are used in different standards. The equation used in this study is recommended by the British Standards-ISO $5167^{[17]}$, which is the Reader-Harris/Galagher equation.

Using a similar approach for the calculation of fluid flow rate across the orifice plate, the relationship between the pressure drop across the filter and the flow rate was developed, Eq. 2:

$\rho \mathrm{Q}_{\text {row }}=\beta \frac{\pi}{4} \mathrm{w}^{2} \sqrt{\frac{2 \rho \Delta \mathrm{p}}{1-\left(\frac{\mathrm{w}}{\mathrm{d}_{\mathrm{o}}}\right)^{4}}}$

Where:

$\mathrm{Q}_{\text {row }}=$ The flow rate across the window

$\mathrm{B}=$ The kinetic correction coefficient

$\Delta \mathrm{p}=$ The pressure drop across a window

$\mathrm{w}=$ The window diameter

$\mathrm{d}_{\mathrm{o}} \quad=$ The equivalent diameter

Therefore, equating Eq. 1 and 2 the kinetic correction coefficient can be expressed as:

$\beta=\frac{4 \rho Q}{w^{2} \pi} \sqrt{\frac{1-\left(\frac{w}{d_{o}}\right)^{4}}{2 \rho \Delta p}}$ 
The equivalent diameter was derived such that the volume of a tube of length $L$ and diameter $d_{o}$ was equal to the total volume of all the cells $\mathrm{V}_{\text {TCELL }}$ in a row of length L. That is:

$$
\pi \mathrm{L} \frac{\mathrm{d}_{0}^{2}}{4}=\mathrm{V}_{\text {TCELL }}
$$

or

$$
\mathrm{d}_{0}=2 \sqrt{\frac{\mathrm{V}_{\mathrm{TCELL}}}{\pi \mathrm{L}}}
$$

The total volume of the cell was calculated by adding up the volumes of the entire spherical cell on a row and subtracting the overlapping volumes that created the windows. That is:

$$
\mathrm{V}_{\mathrm{TCELL}}=\mathrm{MV}_{\mathrm{CELL}}
$$

Where:

$\mathrm{V}_{\mathrm{CELL}}=\mathrm{A}$ cell volume

$\mathrm{M}=$ The number of orifices in the row of cells across the filter, given by:

$$
M=\frac{L}{\sqrt{d^{2}-w^{2}}}
$$

and

$$
\mathrm{V}_{\mathrm{TCELL}}=\frac{\pi \mathrm{d}^{3} \mathrm{~L}}{12 \sqrt{\mathrm{d}^{2}-\mathrm{w}^{2}}}\left(\left(2-3 \mathrm{~B}\left(3 \mathrm{k}^{2}+\mathrm{B}^{2}\right)\right)\right.
$$

Where:

$\mathrm{B}=1-\sqrt{1-\mathrm{k}^{2}}$

$\mathrm{k}=\mathrm{w} / \mathrm{d}$

Hence, for a known flow rate and the pressure drop across the windows the kinetic correction coefficients could be calculated using Eq. 1-5.

\section{RESULTS}

Using the experimental data from the multiple orifice physical scale model, correction coefficient $\beta$ was calculated, by applying Eq. 1-5, for each window fitted with pressure tapings. The experimental data and

\begin{tabular}{|c|c|c|c|c|c|c|}
\hline \multirow{2}{*}{$\begin{array}{l}\text { Cell } \\
\text { diameter, } \\
\mathrm{d}(\mathrm{mm})\end{array}$} & \multirow{2}{*}{$\begin{array}{l}\text { Window } \\
\text { diameter } \\
\mathrm{w}(\mathrm{mm})\end{array}$} & \multirow{2}{*}{$\begin{array}{l}\text { Fluid flow } \\
\text { rates Q } \\
\left(\mathrm{m}^{3} \sec ^{-1}\right)\end{array}$} & \multicolumn{4}{|c|}{ Kinetic correction coefficients } \\
\hline & & & $\beta 1$ & $\beta 2$ & $\beta 3$ & $\beta 4$ \\
\hline 10 & 6.00 & $1.17 \mathrm{E}-03$ & 2.2 & 2.2 & 2.2 & 2.2 \\
\hline 10 & 6.00 & $1.15 \mathrm{E}-03$ & 2.2 & 2.2 & 2.2 & 2.2 \\
\hline 8 & 6.00 & $1.08 \mathrm{E}-03$ & 3.0 & 2.1 & 2.1 & 2.0 \\
\hline 8 & 6.00 & $1.14 \mathrm{E}-03$ & 2.8 & 2.1 & 2.1 & 2.0 \\
\hline 8 & 4.66 & $1.01 \mathrm{E}-03$ & 2.8 & 3.0 & 2.9 & 3.5 \\
\hline 8 & 4.66 & $1.07 \mathrm{E}-03$ & 2.9 & 3.1 & 3.0 & 3.5 \\
\hline 9 & 5.66 & $1.20 \mathrm{E}-03$ & 2.2 & 2.6 & 2.2 & 2.5 \\
\hline 9 & 5.66 & $1.26 \mathrm{E}-03$ & 2.3 & 2.7 & 2.3 & 2.5 \\
\hline 11 & 6.00 & $1.21 \mathrm{E}-03$ & 2.1 & 2.1 & 2.1 & 2.1 \\
\hline 11 & 6.00 & $1.26 \mathrm{E}-03$ & 2.1 & 2.0 & 2.0 & 2.1 \\
\hline 11 & 4.70 & $1.11 \mathrm{E}-03$ & 2.7 & 2.7 & 2.7 & 2.8 \\
\hline 11 & 4.70 & $1.17 \mathrm{E}-03$ & 2.9 & 3.0 & 2.7 & 2.9 \\
\hline
\end{tabular}
the calculated coefficients are shown in Table 1.
Table 1: Kinetic correction coefficients from the multiple orifice physical scale model at windows 1,23 and 4, i.e., $\beta 1, \beta 2$, $\beta 3, \beta 4$

\section{DISCUSSION}

The results from analysis show that the kinetic correction coefficients calculated from the experimental data varied from 2.1-3.6. The modal class was found to be between 2-2.4 with an average kinetic correction coefficient of 2.24. This value for the kinetic correction coefficient determined from the multiple orifice physical scale model corroborates the result offered by Adigio et al. ${ }^{[16]}$. This implied that the MOM model can be calibrated without the use of graphs and graph fitting.

\section{CONCLUSION}

This study has established a new method for the determination of the kinetic correction coefficient of the MOM model. The kinetic correction coefficient of the MOM model has been determined by directly applying physical scale model similar to the conceptual model. The conceptual model used for the development of the MOM model was in this case designed and manufactured for the first time to generate the data for this research study.

This method of model calibration has reduced the computational time of calibrating the mathematical model, eliminating the use of graphs and "graph fitting" to solve such problems.

\section{ACKNOWLEDGEMENT}

This research was only possible due to the help I received from many people. The Niger Delta University Bayelsa State, Nigeria is acknowledged for financial support. I also thank Loughborough University, UK for technical support. Particular thanks must go to my research supervisor Colin Garner for his patience and unfailing encouragement. 


\section{REFERENCES}

1. Heywood, J.B., 1988. Internal Combustion Engine Fundamentals, International Edition, McGraw-Hill Book Co., Singapore, ISBN: 0-07-100499-8. pp: 620-646.

2. Garshick, E., F. Laden, J.E. Hart, B. Rosner, T.J. Smith, D.W. Dockery and F.E. Speizer, 2004. Lung cancer in railroad workers exposed to diesel exhaust. Environ. Health Perspect., 112: 1539-1543. DOI: 10.1289/ehp.7195

3. Warheit, D.B., B.R. Laurence, K.L. Reed, D.H. Roach, G.A.M. Reynolds and T.R. Webb, 2004. Comparative pulmonary toxicity assessment of single-wall carbon nanotubes in rats. Toxicol. Sci., 77: 117-125. DOI: 10.1093/toxsci/kfg228

4. Brown, D.M., K. Donaldson, P.J. Borm, R.P. Schins and M. Dehnhardt, 2004. Calcium and ROSmediated activation of transcription factors and TNF- $\alpha$ cytokine gene expression in macrophages exposed to ultra-fine particles. Am. J. Phys. Lung Cell Mol. Phys., 286: 344-353. http://cat.inist.fr/?aModele=afficheN\&cpsidt= 15421220

5. Nikula, K.J., G.L. Finch, R.A. Westhouse, J. Seagrave, J.L. Mauderly, D.R. Lawson and M. Gurevich, 1999. Progress in understanding the toxicity of gasoline and diesel engine exhaust emissions. society of automotive engineers. Technical paper series.

http://www.osti.gov/bridge/servlets/purl/771098g0 1oIN/native/771098.pdf

6. Dybdahl, M., L. Risom2, P. Mùller, H. Autrup and H. Wallin et al., 2003. DNA adduct formation and oxidative stress in colon and liver of big blue rats after dietary exposure to diesel particles. Carcinogenesis, 24: 1759-1766. DOI: 10.1093/carcin/bgg147

7. Health Effects Institute, HEI, Perspectives, 2002. Understanding the health effects of components of the particulate matter mix: Progress and next steps. http://rds.yahoo.com/_ylt=A0geu4_NJOhJn9cAiadXNyo A;_ylu=X3oDMTE1dDhwNGY0BHNIYwNzcgRwb3M DNwRjb2xvA2FjMgR2dGlkA01BUDAwN18xMDY/SIG=12bijfbsq/EXP=1240036941/**http\%3a//www.healt heffects.org/Pubs/annualreport01-02.pdf

8. United State Environmental Protection Agency, 2002. Health Assessment Document for Diesel Engine Exhaust. US Environmental Protection Agency, Office of Research and Development, National Center for Environmental Assessment, Washington Office, Washington, DC, EPA/600/8-90/057F. http://oaspub.epa.gov/eims/eimscomm.getfile?p_do wnload_id=36319
9. World Health Organization, 2003. Health Aspects of Air Pollution with Particulate Matter, Ozone and Nitrogen Dioxide. Report on WHO Working Group, Bonn, Germany. EUR/03/5042688

http://rds.yahoo.com/_ylt=A0geu9SpCehJvQoAbR ZXNyoA;_ylu=X3oDMTE1ZGw0b24zBHNIYwN zcgRwb3MDMQRjb2xvA2FjMgR2dGlkA01BUD AwN18xMDY-

/SIG=11v59svcc/EXP=1240029993/**http\%3a//w ww.euro.who.int/document/e79097.pdf

10. Arey, J., 2004. A tale of two diesels. Environ. Health Perspect., 112: 812-813. DOI: 10.1289/ehp.7031

11. Swiss Agency for the Environment, Forest and Landscape, SAEFL, 3003 Berne, 2000. Particulate Trap for Heavy Duty Vehicles. Environmental Documentation No. 130. http://rds.yahoo.com/_ylt=A0geu 7hnDehJywMANThX NyoA;_ylu=X3oDMTE1ZGw0b24zBHNIYwNzcgRwb3 MDMQRjb2xvA2FjMgR2dGlkA01BUDAwN18xMDY/SIG=16oq3agei/EXP=1240030951/**http\%3a//www.ba fu.admin.ch/luft/00596/00597/00609/index.html\%3flang $=$ en $\% 26$ download $=$ NHzLpZig7t, $\ln$ 6 6 IONTU042l2Z6ln 1 ad1IZn4Z2qZpnO2Yuq2Z6gpJCDeIB7fmym162dpYbU zd,Gpd6emK2Oz9aGodetmqaN19XI2IdvoaCVZ,s-.pdf

12. Mayer, A., 1998. Selection Criteria for Diesel Particulate Trap Systems: VERT Experience. http://www.dieselnet.com/papers/9812mayer.html

13. Matter, M.A.U., J. Czerwinski and N. Heeb, 1999. Effectiveness of particulate traps on construction site engines: VERT final measurements. http://www.dieselnet.com/papers/9903mayer/

14. Nauss, K., 1997. Diesel exhaust: A critical analysis of emissions, exposure and health effects. DieselNet technical report. http://www.dieselnet.com/papers/9710nauss.html

15. Masoudi, M., 2005. Pressure drop of segmented diesel particulate filters. Society of automotive enginers technical paper series 2005-01-0971. http://www.delphi.com/pdf/techpapers/2005-01-0971.pdf

16. Adigio, E.M., J.G.P. Binner, C.P. Garner, R.J. Hague and A.M. Williams, 2008. Modeling gas flow pressure gradients in gelcast ceramic foam diesel particulate filters. Proc. IMechE Part D: J. Automobile Eng., 222: 1471-1487. DOI: 10.1243/09544070JAUTO508

17. Reader-Harris, M.J. and J.M. McNaught 2005. Best Practice Guide Impulse Lines for DifferentialPressure Flowmeters, NEL No.: 2005/224. http://rds.yahoo.com/_ylt=A0geu8g6H.hJYw4APNFXNy oA;_ylu=X3oDMTE2bWZ2MzcwBHNIYwNzcgRwb3M DMTEEY29sbwNhYzIEdnRpZANNQVAwMDdfMTA2/ SIG=1442s42ps/EXP=1240035514/**http\%3a//www.idconline.com/technical_references/pdfs/instrumentation/Diff erential\%2520pressure\%2520meters_nel.pdf 